\title{
ŚREDNIOWIECZNE MŁYNY WODNE I ICH WPŁYW NA PRZEMIANY STOSUNKÓW WODNYCH NA PRZYKŁADZIE ZLEWNI OBRY SKWIERZYŃSKIEJ
}

\author{
ALFRED KANIECKI, DOROTA BRYCHCY
}

\begin{abstract}
Zakład Hydrologii i Gospodarki Wodnej, Instytut Geografii Fizycznej i Kształtowania Środowiska Przyrodniczego, Uniwersytet im. Adama Mickiewicza w Poznaniu
\end{abstract}

\begin{abstract}
From the mid-13th century onwards, water provided energy to water mills located in the catchment of Obra Skwierzyńska. They did not only mill grain but also produced groats, malt, fulled cloth, tanned skin, cut wood, ground metal and produced paper. Their considerable growth in number in this area was observed at the end of the 14th century as a result of the Polish-Lithuanian Union. This area found itself on the main trade routes. During the period from the 13th to 19th century, water mills had a significant influence on the formation of the hydrological system of the catchment area. Their building and functioning was connected with the formation of mill-pond trough, dams, building weirs and mill ditches as well as bypass channels.

The river network adaptation for the abovementioned purposes also includes: river mining, river bed cleaning, river banks strengthening with timber piles and boards, changes in the amount of water in watercourses. Water from lakes, springs and other water races was guided to watercourses on which several water -mills were built. Water mills were built in meadows or wetlands, trough-out canals and trenches gathering water in millponds were dug out. This kind of permanent dewatering of wet areas and changing them into meadows and pastures; also, water energy utilization for production influenced the evolution of society, forced it to optimize the utilization of surface water resources.
\end{abstract}

Keywords: Skwierzyńska Catchment Area, mediaeval water mills, water relations

Wczesne dzieje młynarstwa na ziemiach Wielkopolski są ciagle stosunkowo słabo rozpoznane. Młyny wodne, które zaczęły rozpowszechniać się w Polsce w XIII w., odegrały bardzo ważną rolę w rozwoju sił wytwórczych, bowiem przyspieszyły różne procesy życia gospodarczego. Sam młyn poruszany energią wodna, mielący szybko ziarna na mąkę czy rozbijający za pomocą stęporów rudę, ziarno na kaszę lub słód albo nasiona roślin oleistych bądź ubijający sukno, skórę czy żelazo, stanowił bardzo skomplikowane przedsięwzięcie. Chcąc zapewnić w miarę ciagłą jego pracę, należało: przystosować odpowiednio koryto cieku, wzmocnić jego brzegi, budować groble piętrzące wodę, kopać rowy i kanały doprowadzające wodę do młyna itp.

Pojawienie się i rozpowszechnienie młyna wodnego stanowiło, nie tylko w sposobie przemiału zbóż, rewolucyjny przełom. Zastąpienie prymitywnych żaren domowych kamieniami młyńskimi poruszanymi energią wodną stanowiło znaczący postęp cywilizacyjny, tym bardziej że ich wydajność była 
wielokrotnie wyższa od pracy ludzkiej. Wprowadzenie młynów wodnych przyczyniło się również do długotrwałych zmian stosunków wodnych w dolinach rzecznych.

Analizę wpływu działalności młynów wodnych na obszarowe przemiany stosunków wodnych przeprowadzono na obszarze zlewni Obry Skwierzyńskiej, stanowiącym od XIII w. obszar przygraniczny Wielkopolski z Brandenburgią i Księstwem Głogowskim.

Rozpatrywany teren obejmuje więc północną część Doliny Środkowej Obry (315.63), odwadnianą przez Północny Kanał Obry, a stanowiącą część Pradoliny Warszawsko-Berlińskiej, oraz obszary wysoczyznowe Pojezierza Poznańskiego (315.51) i Pojezierza Lubuskiego (315.4) według podziału J. Kondrackiego (1998).

Od Kopanicy do ujścia Obra przepływa przez Bruzdę Zbąszyńską (315.44) zwaną również Obniżeniem Obry. Składa się ona z południkowej rynny jezior zbąszyńskich oraz z wygiętej łukowato na zachód doliny Obry. Wyścielają ją piaski akumulacji rzecznej i lodowcowej. W jej obrębie występuje kilka dużych jezior, przez które Obra przepływa. Bruzdę Zbąszyńską charakteryzują liczne formy martwego lodu w postaci ozów, kemów i terasów kemowych.

Wschodnią część zlewni Obry Skwierzyńskiej w obrębie Pojezierza Poznańskiego wyróżnia kilka mniejszych jednostek krajobrazowych różniących się cechami rzeźby, genezą i budową geologiczną. Stanowią je: Pojezierze Międzychodzko-Pniewskie (315.512) na północy zbudowane głównie z glin zwałowych, Wał Lwówecko-Rakoniewicki (315.513), będący formą ostańcową starszych zlodowaceń i rozległa Równina Nowotomyska (315.511) zbudowana z piasków sandrowych. Dominują tam obszary mało zróżnicowane hipsometrycznie. Obszar ten odwadniają: Kanał Grabarski, Dojca, Szarka i Czarna Woda. Natomiast w obrębie Pojezierza Lubuskiego, obejmującego zachodnią część zlewni Obry Skwierzyńskiej, wyróżnia się Wał Zbąszynkowski ciaggnący się wzdłuż Bruzdy Zbąszyńskiej. Jest to teren wyraźnie zróżnicowany hipsometrycznie; najwyższe wzniesienie koło Bukowca osiagga rzędną 133 m n.p.m. Obszar ten obniża się do około 80 m n.p.m. pod Babimostem, a powierzchnia w obrębie Bruzdy Zbąszyńskiej oscyluje przy wartości 50 m n.p.m. Głównym ciekiem jest tutaj Paklica, płynąca szeroką, zabagnioną doliną. Obszary wysoczyznowe od pradoliny i Obniżenia Obry dzielą wyraźne zbocza o wysokości rzędu 20-30 m.

Rozpatrywany teren budują głównie piaski wodnolodowcowe, lodowcowe i rzeczne. Zatem charakteryzuje się on względnie dużą chłonnością infiltracyjną wód opadowych. Duża również liczba jezior na tym obszarze sprawia, że wahania stanów wody w ciekach są stosunkowo niewielkie. Obszary zbudowane z glin zwałowych, a więc o małej zdolności retencyjnej, występują tylko w rejonie: Zbąszynia, Kargowej, Wolsztyna oraz Nowego Tomyśla i stanowią stosunkowo niewielkie powierzchnie. Natomiast w okolicy Międzyrzecza na powierzchni terenu odnotowywane osady zastoiskowe, głównie iły i mułki. 
Przy próbie odtworzenia dziejów młynów wodnych na tym obszarze korzystano z różnych materiałów archiwalnych. Były nimi głównie historyczne materiały źródłowe oraz stare przekazy kartograficzne. Część historycznych materiałów źródłowych udostępniona została dzięki opracowaniu tomów Kodeksu Dyplomatycznego Wielkopolski (KDW) pod redakcją J. Zakrzewskiego, F. Piekosińskiego i A. Gąsiorowskiego oraz Stownika geograficzno-historycznego województwa poznańskiego pod redakcją S. Chmielewskiego i A. Gąsiorowskiego czy ostatnio T. Jurka, co ułatwiło badanie tego problemu. Są to najczęściej dokumenty dotyczące zezwolenia na budowę młyna, jego sprzedaży lub użytkowania. Natomiast z materiałów kartograficznych wykorzystano informacje znajdujące się na mapach: J.A. Rizzi-Zannoniego (1772) i T.Ph. von Pfaua (1778) oraz D. Gilly'ego (1805). Dotyczyły one lokalizacji młynów wodnych, występowania stawów przy nich, ewentualnie sposobu doprowadzenia wody do nich.

Problem wpływu budowy młynów wodnych na przemiany środowiska przyrodniczego przedstawiony był w pracach: M. Dembińskiej (1973), M.J. Losia (1978), A. Kanieckiego (1993, 1999, 2004) i Z. Podgórskiego (2004). Ciągle jednak nie jest w pełni rozpoznany.

Zachodnia Wielkopolska we wczesnym średniowieczu była obszarem słabo zagospodarowanym w porównaniu z okolicami: Poznania, Gniezna, Kruszwicy, Lądu czy Żnina. Tereny wysoczyznowe obejmowała zwarta puszcza, przerywana tylko niewielkimi powierzchniami gruntów użytkowanych rolniczo, a w dolinach rzek dominowały raczej rzadkie lasy łęgowe i trzcinowiska. Tylko na wyższych fragmentach den dolinnych występowały błonia nadrzeczne. Obszary bezleśne zajmowały więc wtedy niewielkie tylko przestrzenie. Osadnictwo miało wówczas charakter wyspowy wśród różnego rodzaju form zalesienia.

Doliny Warty i Noteci na północy rozpatrywanego obszaru oraz Obry Skwierzyńskiej, rozległe i bagniste, stanowiły wówczas naturalne granice broniące dostępu do Wielkopolski. W miejscach, gdzie możliwe były przeprawy przez te doliny, tworzyły się punkty osadnicze czerpiące korzyści z tego położenia. Z ważniejszych wymienić tu można: Santok (X w.), Międzyrzecz (1005 r.), Przemęt (1210 r.), Zbąszyń (1231 r.), Skwierzynę (1251 r.), Babimost (1257 r.) czy Trzciel (1252 r.). Do tych przepraw przez niedostępne w innych miejscach doliny rzeczne dowiązywały ważne lądowe szlaki handlowe. Rozwój ich na większą skalę nastąpił wraz z rozpowszechnieniem zaprzęgu ciągnionego przez konie lub woły. Wcześniej dominował transport wodny. Przy tych szlakach lądowych również powstawały różnego typu osady. Do $1300 \mathrm{r}$. wymieniano na obszarze opracowania około 30 osad.

Jak pisał Hładyłowicz (1932), cały ten teren zachodniej Wielkopolski pokryty był wielką puszczą i dopiero od XIV w. zaznacza się tam silny wzrost osadnictwa. Kolejny wzrost gęstości osad obserwujemy tu dopiero w XVII i XVIII w. 
i wiąże się on z tzw. kolonizacją olęderską, która zagospodarowywała tereny podmokłe, przystosowując je do uprawy łąkowej i rolnej.

Pierwsze informacje dotyczące młynów wodnych na obszarze Wielkopolski pochodzą z XII i XIII w. i nie są zbyt liczne. Więcej jest ich dopiero w XV w., kiedy nastapił gwałtowny wzrost liczby młynów, a ponadto zachowało się dużo materiałów archiwalnych z tego okresu, co umożliwiło bardziej dokładne określenie zasad funkcjonowania młynów, niekiedy ich konstrukcji czy czasu pracy.

Pierwsze informacje o młynach wodnych wiążą się z szerokimi i bagnistymi dolinami rzek - Obry i Paklicy. Zdawać by się mogło, że nie są to obszary sprzyjające ich budowie. Decydowały tu jednak dogodność miejsca lokalizacji, $\mathrm{z}$ reguły na wyższych fragmentach terasy zalewowej i łatwość doprowadzenia wody do młyna. W okresie późniejszym dominowało lokowanie młynów nad niewielkimi ciekami, szczególnie w pobliżu ujść do większych rzek bądź poniżej jezior.

Za pierwszą wiadomość o młynie wodnym na rozpatrywanym obszarze przyjmuje się informację z 1236 r., że młyn w Gościchowie, jaki zbudował komes Bronisz i w którym osadził na trzy lata Niemca Wilhelma, przekazany został mnichom opactwa cysterskiego w Paradyżu (KDW-I-198). W 1236 r. komes Przybigniew nadał również klasztorowi w Paradyżu wodę, tzn. rzekę lub jezioro, w celu budowy na niej młyna (KDW I-191). Z dokumentów wynika, że w XIII w. wybudowano na tu następujące młyny w: Gościkowie (przed 1236 r.), Obrze (1238 r.), Jażyńcu koło Wolsztyna (1238 r.), Niałku (1285 r.), nad Lubniewicą (1287 r.) i przy Jeziorze Biskupim w Pszczewie (1288 r.).

W XIV w. notuje się powstanie podobnej liczby młynów wodnych na tym obszarze. Wymienia się wtedy następujące młyny: Stary i Nowy Młyn w Karpicku koło Wolsztyna (1303 r.), młyn na Obrze koło Kiełczowa (1310 r.), młyny Hamistrad (1316 r.) i w Kręsku koło Zbąszynia, na rzece Osecina w pobliżu Gniewowa (1356 r.), na rzece Karna (1364 r.) i w Targowisku (1376 r.).

Przedstawione przy poszczególnych młynach daty dotyczą jedynie faktu odnotowania ich istnienia po raz pierwszy. Te pierwsze wzmianki źródłowe nie muszą się więc odnosić do daty ich powstania.

Dopiero po 1385 r. zaznacza się znaczący wzrost liczby młynów wodnych na rozpatrywanym obszarze. Na rycinie 1 przedstawiono rozmieszczenie młynów o bezspornej lokalizacji. Na pewno było ich więcej, jednak często młyny zmieniając właścicieli, zmieniały nazwy. Dlatego zwykle trudno określić czy różne nazwy odnoszą się do tego samego młyna czy do różnych. O ile w XIII i XIV w. wzrost liczby młynów wodnych na tym obszarze był dość powolny, to w wieku XV można już mówić o powszechnym ich tam występowaniu. Gwałtowny wzrost liczby młynów wodnych na rozpatrywanym obszarze, jaki nastąił na przełomie XIV i XV w., wiązać należy z ożywieniem ruchu handlowego na 


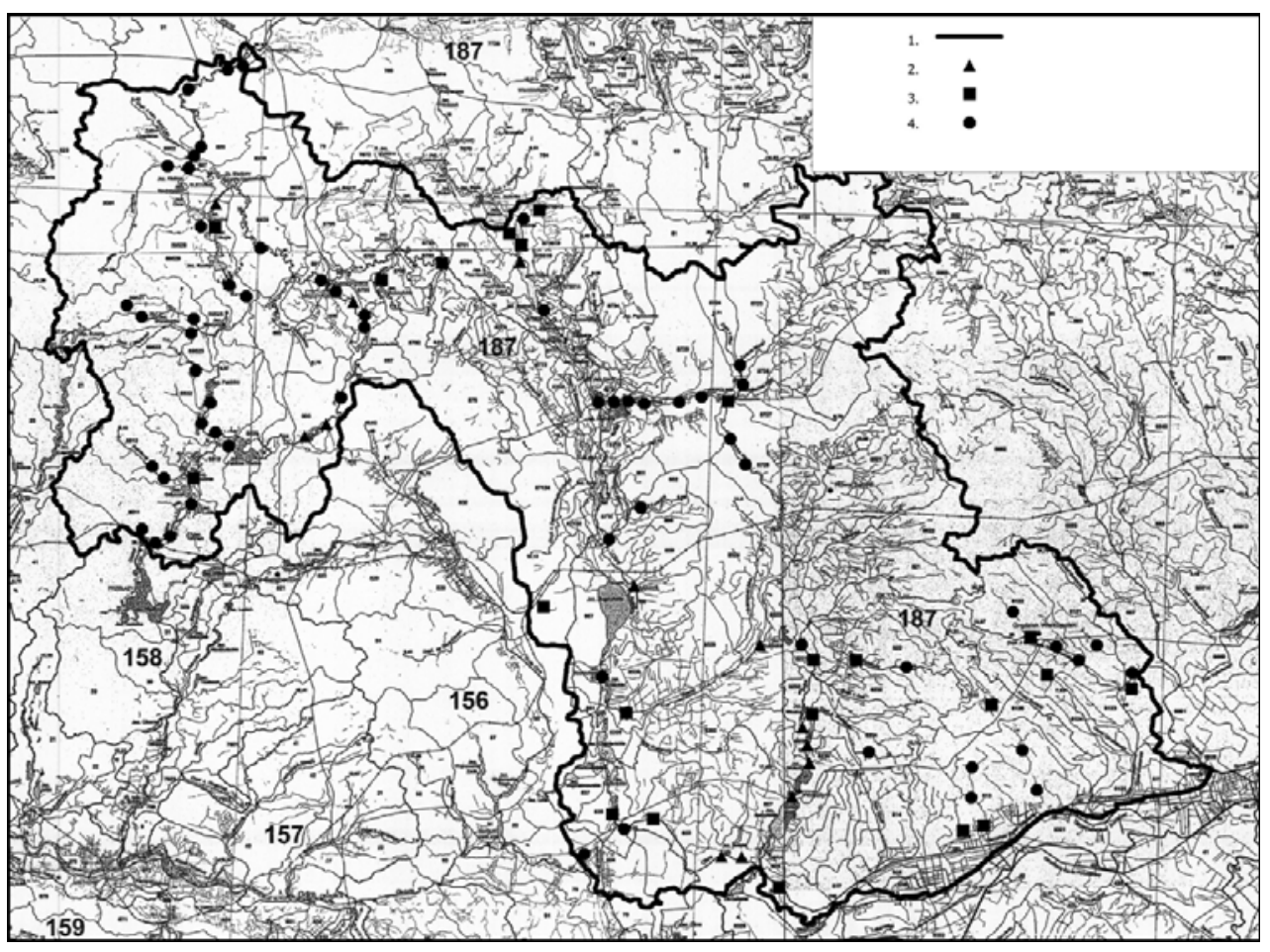

Ryc. 1. Lokalizacja młynów wodnych powstałych od XIII do XVI w.

1 - granica zlewni Obry Skwierzyńskiej, 2 - wybudowanych do 1385 r., 3 - wybudowanych w latach 1385-1500, 4 - wybudowanych po roku 1501

Fig. 1. Distribution of water mills in the XIII-XVI th century

1 - bondary of Skwierzyńska Obra catchment, 2 - water mills build up to 1385, 3 - water mills build 1385-1500, 4 - water mills build after 1501

szlaku łączącym Litwę i Ruś poprzez Torun i Poznań z Niemcami w wyniku unii polsko-litewskiej. Po zwycięskiej wojnie trzynastoletniej z Krzyżakami nastapiła dalsza intensyfikacja handlu z Niemcami.

Młyny wodne pomimo dużych kosztów ich budowy oraz eksploatacji były jednak inwestycjami bardzo dochodowymi, stąd tak liczne wzmianki o nich w materiałach źródłowych z XIII i XIV w. Zwiększenie areału ziemi uprawnej, stosowanie nowych narzędzi pracy, w tym pługa, wzrost plonów i stopy życiowej ogółu społeczeństwa spowodowały zwiększone zapotrzebowanie na przetworzone produkty zbożowe, zwłaszcza w miastach i większych skupiskach ludności. Młyny wodne były instytucjami trwałymi i niekiedy istniały w tych samych miejscach przez 500-600 lat (Kaniecki 1993).

Prawo budowy młyna miał pierwotnie tylko panujący, niezależnie na jakim terytorium młyn się znajdował. Samo prawo własności gruntowej nie dawało prawa do budowy młyna na swoim gruncie, jeżeli nie było ono zawarte w akcie 
nadania. Stopniowo jednak panujący zrzekał się tego monopolu na rzecz właścicieli terenów, na których miały być one wybudowane.

Konstrukcja skomplikowanych urządzeń, jakimi były niewątpliwie młyny wodne, znana była budowniczym młynów już w XIII w. Znano sposoby odpowiedniego wykorzystania terenu, spadku wód oraz tworzenia sztucznych wodospadów oraz sposób, jak wykorzystać prąd wody, jak go wzmocnić lub osłabić. $\mathrm{Z}$ upływem czasu zaczęto $\mathrm{w}$ coraz większym stopniu adaptować teren i sieć wodną na potrzeby pracy młynów wodnych. Wykorzystywano w coraz większym stopniu drobne cieki o niewielkim spadku zwierciadła wody i nieznacznym przepływie. W okresie letnim, szczególnie na obszarach bagiennych, często traciły one wode.

Początkowo młyny lokowano w miejscach niewymagających specjalnych prac adaptacyjnych. Wykorzystywano głównie miejsca załamania spadku podłużnego w ciekach, charakteryzujące się mało zmiennym przepływem w ciągu roku i leżące poza zasięgiem wód powodziowych. Były to więc dolne biegi dopływów, najczęściej w strefie zboczowej doliny rzeki głównej bądź miejsca poniżej wypływu cieku z jeziora. $\mathrm{W}$ obu przypadkach taka lokalizacja zapewniała w miarę mało zmienny w czasie dopływ wody na koło młyńskie.

Pierwsze młyny wodne na rozpatrywanym obszarze budowano zarówno na Obrze, jak i na jej większych dopływach, tj. Paklicy i Dojcy. Szczególnie dużo - $\mathrm{i}$ to stosunkowo wcześnie, bo siedem wybudowano ich na Dojcy. W XIII i XIV w. wymienia się tam wtedy młyny: Niałecki, Ruchocki, Stary i Nowy Młyn w Karpicku, a w pierwszej połowie XV w. jeszcze młyny - Borujski i Zawada. Później wybudowano jeszcze Kuźnię (Hammer - Kuźnica).

Drugą taką niewielką rzeką, na której wybudowano 10 młynów wodnych, była Czarna Woda mająca swe źródła powyżej Lwówka i wpadająca do Obry w Trzcielu. Na tym cieku i jego dopływach zlokalizowano następujące młyny: Węgielny, Sappolny, Mitręga, Bobrówka, Mniszek, Papiernia, Szklarka, Hamrzysko, Hamer i w Miedzichowie.

Większość młynów budowano nad mniejszymi ciekami, gdzie adaptacja cieku na ich potrzeby była mniej kosztowna. Adaptacja sieci rzecznej do pracy młyna wodnego wymagała pogłębienia koryta cieku powyżej młyna w celu: wzmocnienia jego siły drenującej i zwiększenia napływu wód gruntowych, spiętrzenia jego wód i budowy stawu, jednego lub kilku, budowy grobli zabezpieczających wody w stawach, doprowadzenia rowami lub kanałami wody z różnych odległości do stawu młyńskiego. Te wszystkie umiejętności musiał opanować średniowieczny młynarz, a ponadto musiał przewidzieć skutki tych prac i zabezpieczyć się przed ich niekorzystnym wpływem.

Miejsce na budowę młyna wybierano bardzo starannie. Często takie miejsce odkupywano (KDW-II-879). Jeżeli znajdowało ono się w obrębie dwóch dziedzin, to budujący młyn musiał drugiemu właścicielowi tego miejsca płacić sto- 
sowne odszkodowanie, na przykład bezpłatny przemiał w tym młynie do końca życia.

Również za prawo spiętrzania wody w rzece musiano odpowiednio nagrodzić właściciela gruntów leżących powyżej. Z 1360 r. zachował się dokument dotyczący takiego spiętrzenia w rzece Dojcy. Pielgrzym z Karpicka mógł spiętrzać wodę w Dojcy na potrzeby młynów w Karpicku, zalewając brzeg należący do Tomasza z Chorzemina. W zamian Tomasz i jego następcy mogą w Starym Młynie mleć co tydzień korzec ziarna bez opłaty, a w nowo powstałym stawie mogą zakładać 20 więcierzy i co tydzień łowić ryby siecią słęb. Z kolei Pielgrzym i jego następcy w Chorzeminie mogą pobierać na potrzeby dwóch młynów w Karpicku drewno i piasek (KDW-III-1426).

Początkowo były to młyny mączne napędzane jednym kołem. W XVI w. w młynach występowało już więcej kół, najczęściej dwa, ale w Skwierzynie czy Międzyrzeczu natrafiamy na młyny o trzech kołach. Obok młynów mącznych zaczęły się pojawiać: folusze, tartaki, kuźnice, papiernie itp. Przy młynach tworzyły się często osady, które nazwy brały od rodzaju młyna wodnego. Przy hutach szklanych nosiły one nazwę Huty lub Szklarki, przy kuźnicach - Hamry, Hamrzysko, Kuźnik, Kuźnica, przy tartakach - Piły, Piłki, przy młynach mącznych - Mączniki, przy foluszach - Folusz itp.

Pierwsze informacje o młynach wodnych wiążą się z obecnością stawów, a więc z przegrodzeniem rzeki. Na małych ciekach długotrwała praca młyna wodnego w ciagu roku nie byłaby możliwa bez wybudowania stawu retencjonującego możliwie dużą ilość wody. Na ogół były to stawy przepływowe, w związku z czym stosunkowo szybko następowało ich zamulanie, co z kolei wymagało częstego oczyszczania ich misy po spuszczeniu wody. Wodę ze stawów najczęściej spuszczano co cztery lata w celu wyłowienia ryb i oczyszczenia ich niecek (Słownik..., 1982-2009). Stawy nie tylko zapewniały pracę młyna wodnego w czasie stanów niskich, ale również przyczyniały się do wyrównywania stanów wody w cieku w ciagu roku.

Do form związanych bezpośrednio z budową młynów wodnych i z ich funkcjonowaniem zaliczyć należy groble spiętrzające wodę w zbiornikach wodnych usytuowanych powyżej młyna. Budowa stawu młyńskiego umożliwiała zwiększenie spadku wody spadającej na koło lub koła młyńskie, a tym samym wzmożenie jej siły uderzeniowej. Ilość wody spadającej na koła regulowano jedną lub kilkoma zastawkami. Zbiornik wodny usytuowany powyżej młyna retencjonował również pewną ilość wody, co w warunkach stanów niżówkowych w ciekach umożliwiało wydłużenie jego czasu pracy. Często obok stawu głównego, przeznaczonego dla pracy młyna, kopano również kilka mniejszych, w których poza retencjonowaniem wody prowadzono również hodowlę ryb.

Średniowieczne młyny wodne na ogół wiązały się z obecnością stawów. Budowano je, przegradzając rzekę groblą i spiętrzając jej wody. Czyli te pierw- 
sze młyny wodne miały koło podsiębierne (walne), które poruszał prąd wody napierający na łopatki zanurzone w niej aż po obwód wieńca.

Groble spiętrzające wodę powyżej młyna w zbiornikach wodnych stanowiły nieodłączny element krajobrazu młyńskiego. Szczególnie często występowały one przy młynach wodnych usytuowanych nad małymi ciekami. Ogólnie przyjmuje się, że przy zlewniach o powierzchniach większych od $600 \mathrm{~km}^{2}$ stawów nie zakładano, bowiem ilość wody w cieku była wystarczająca do poruszania kół młyńskich przez znaczną część roku (Łoś 1978). Na ogół groblę stanowił nasyp ziemny zbudowany z materiału spoistego, tj. gliny lub iłu, wzmocniony palami lub konstrukcją drewnianą, którego zbocza pokrywano darnią chroniącą przed ich rozmyciem. Wysokość grobli czołowych była różna i wahała się najczęściej od 3 do 4 m, natomiast długość od kilkudziesięciu do kilkuset metrów. Usytuowane były one poprzecznie lub skośnie w odniesieniu do przebiegu koryta cieku. Były to więc stawy przepływowe.

Rozmiary stawów młyńskich były bardzo różne od małych do dużych. Klasztor w Obrze na przykład mógł posiadać na swych stawach młyńskich dwóch rybaków, którzy łowili ryby sieciami zwanymi słępy.

Znamy wymiary stawów młyńskich Borowego i Kopermilla poniżej wypływu z Jeziora Bobowickiego z 1563 r. Wody pierwszego spiętrzała grobla o długości około $134 \mathrm{~m}$ (3 sznury). Sam staw był długi na 3 staje, tj. około $1850 \mathrm{~m}$ i szeroki na 8 sznurów, tj. około $350 \mathrm{~m}$, a jego głębokość sięgała od 4 do 6 łokci, tj. od 240 do $360 \mathrm{~cm}$. Z kolei staw Kopermill, usytuowany poniżej Stawu Borowego, miał wymiary: długość około $1050 \mathrm{~m}$, szerokość około $175 \mathrm{~m}$ i głębokość od 90 do $240 \mathrm{~cm}$ (Lustracje..., 1961). Część tych stawów istniała jeszcze na mapach XVIII- i XIX-wiecznych. Do największych należały wtedy: Bobrówka i Mniszek na Czarnej Wodzie, Kopermill na cieku wypływającym z Jeziora Bobowickiego i Ruchocki na Dojcy. Dzisiaj te dawne stawy młyńskie praktycznie nie istnieją bądź pozostały z nich niewielkie tylko zbiorniki wodne.

O sposobie budowania grobel pisał szczegółowo Olbracht Strumieński w książce $O$ sprawie, sypaniu, wymierzeniu i rybieniu stawów, której pierwsze wydanie ukazało się w roku 1573.

Budowa młynów przyczyniła się również do rozwoju rybactwa. W zasadzie już od końca XIII w. często przy nadaniu prawa do budowy młyna wodnego zezwalano właścicielowi na korzystanie $\mathrm{z}$ różnych form połowu ryb; i to zarówno w samej rzece, nad którą ten młyn stał, jak i w stawach podpiętrzających wodę powyżej młyna. Często obok stawu głównego, spiętrzającego wodę na potrzeby młyna wodnego, kopano kilka mniejszych, przeznaczonych do hodowli ryb. O „piscinach”, a więc różnego rodzaju stawach służących do hodowli ryb wspomina się w dokumentach już od XIII w. Na łowienie ryb w stawach i sadzawkach młynarz-dzierżawca musiał otrzymać osobne zezwolenie. W rozliczeniach z właścicielem młyna młynarz musiał oddawać $2 / 3$ złowionych ryb, ale stanowiło to dla niego ważne źródło dochodu. 
Pracę młyna wodnego regulowało szereg przepisów, których celem było niezakłócanie pracy innym młynom. Nie mogły na przykład przeszkadzać w pracy innym młynom usytuowanym na tym cieku. Musiały więc znajdować się w odpowiedniej odległości jeden od drugiego, co uzależnione było zarówno od spadku podłużnego rzeki, jak i od wysokości podpiętrzenia wody w stawie młyńskim. Istniały również przepisy zabraniające nagłego wypuszczania wody ze stawów młyńskich bądź zatrzymywania całej wody. Zastawka młyna powinna być tak regulowana, aby woda nie podtapiała młynów sąsiednich. Brzegi cieków i kanałów w sąsiedztwie młynów należało wzmacniać palami i dylami ażeby uniknąć przesuwania się koryta cieku na skutek erozji bocznej (KDW-VIII-809).

Ponadto spiętrzać należało wodę w stawie tylko do określonej wysokości. W przypadkach spornych, kiedy dochodziło do powstania szkód w sąsiednim młynie, sąd rozjemczy składający się z młynarzy z innych młynów określał wysokość spiętrzania wody. Często oznaczano wysokość spiętrzania poprzez wbicie żelaznego gwoździa w pal znajdujący się przy grobli stawu. W średniowiecznych aktach sądowych zwykle natrafiamy na takie pozwy składane przez właścicieli młynów na właścicieli sąsiadujących z nimi młynów. Szczególnie często takie pozwy spotykamy w przypadku młynów usytuowanych na Dojcy i dotyczą one zalania młynów: Ruchockiego, Niałeckiego oraz Nowego i Starego Młyna w Karpicku. W 1364 r. Świętosławowi, prawdopodobnie właścicielowi jednego z młynów w Karpicku, nakazano jego zburzenie, ponieważ szkodził pracy młyna Niałeckiego (Stownik..., 1982-2009). Z dużej liczby pozwów wynikać by mogło, że zbyt blisko siebie wybudowano te młyny na Dojcy.

Występowanie kilku spiętrzeń wód cieku na potrzeby młynów wodnych przyczyniało się jednak do podnoszenia poziomu wód gruntowych na terenach przyległych i do zwiększenia ich zasobów. Młyny pobudowane nad rzekami $\mathrm{z}$ reguły sąsiadowały $\mathrm{z}$ łąkami lub terenami podmokłymi. Na ogół przekopywano przez nie kanał lub rowy odwadniające tereny podmokłe lub ściagające wodę ze źródła, sąsiedniej rzeki lub jeziora do stawu młyńskiego, stanowiącego rezerwuar wody niezbędny dla pracy młyna. Budowa młynów wodnych przyczyniała się więc do zmiany stosunków wodnych na obszarach przyległych do nich. Spiętrzenie wód w stawie młyńskim powodowało podnoszenie się poziomu wód gruntowych, natomiast budowa rowów odwadniających na obszarach podmokłych w obrębie dna doliny, w celu zwiększenia ilości wód w cieku w czasie trwania stanów niżówkowych, zjawisko odwrotne.

Rowy i kanały ściagające wodę musiały mieć odpowiedni spadek oraz długość i jednocześnie zabezpieczać odwadniany obszar przed zalewami w czasie trwania stanów wysokich w ciekach. Zniszczenie na przykład łąk, wynikające z nieprzestrzegania zasad odwadniania terenu podmokłego, wiązało się ze sporami i karami za spowodowane straty. W średniowiecznych procesach sądowych często występowały tego typu problemy. Dotyczyły one na przykład zalania łąk kmiecych w Kiełpinach w 1537 r. czy przyległych do Ruchockiego Młyna na 
Dojcy przez młynarza z Nowego Młyna w Karpicku lub z Borujskiego Młyna w 1574 r. (Stownik..., 1982-2009). Często w związku z tym dochodziło do zniszczenia grobli. Takie sytuacje natrafiamy w 1418 r. przy młynie Niałeckim albo 1425 r. przy młynie Borujskim, wybudowanych nad Dojca.

Niekiedy budowano sztuczne koryta dla wód wypływających z większego cieku, tzw. młynówki, które kierowano na koło młyńskie. Jeżeli młyn miał więcej niż jedno koło, pogródki rozdzielały nurt, kierując wodę w odpowiednich ilościach na poszczególne koła. Zdarzały się jednak przypadki, że zmieniano bieg młynówek lub cieków, które już wcześniej wykorzystywane były na potrzeby młyna wodnego. Na przykład w 1563 r. Struga Barłożna, która wcześniej zasilała wody stawu Starego Młyna w Karpicku, została skierowana do wielkiego rowu i na koła Nowego Młyna usytuowanego na Dojcy w Karpicku, co doprowadziło do skonfliktowania ich właścicieli (Słownik..., 1982-2009).

O ile w XIII i XIV w. liczba młynów na obszarze objętym opracowaniem była stosunkowo niewielka i zmiany stosunków wodnych spowodowane ich budową oraz funkcjonowaniem miały charakter punktowy czy lokalny, to w miare wzrostu ich liczby zaczęły się one łączyć, tworząc coraz to rozleglejsze strefy. W XVI w., gdy liczba młynów wodnych była największa, można już mówić o wyraźnym wpływie wywołanym ich budową na stosunki wodne obszarów przyległych. W XVII i XVIII w., kiedy to w przypadku Królestwa Polskiego doszło do upadku gospodarczego państwa, zmniejszyła się zarówno liczba młynów wodnych, jak i ograniczenie prac związanych ze zwiększeniem ilości wody w ciekach, nad którymi te młyny pracowały. Przyczyniło się to do skrócenia czasu ich pracy pomimo wzrostu wtedy uwilgotnienia klimatu. O ile w XVI w. było ich na rozpatrywanym obszarze ponad 90 , to w XVIII w. ich liczba zmniejszyła się o jedną trzecią (ryc. 2).

Od połowy XIX w. liczba młynów wodnych zaczęła się wyraźnie zmniejszać. Zastępowały je młyny parowe, bardziej efektywne. Ponadto, prowadzone wtedy intensywne prace odwodnieniowe na obszarach bagiennych, regulacje i prostowanie biegu rzek, zarówno dużych, jak i małych, przyczyniły się do zmniejszenia zasobów wodnych w ich dorzeczach, co również wpłynęło na skrócenie czasu pracy młynów wodnych. Ponadto zamknięcie młyna wodnego często prowadziło do likwidacji piętrzeń i zmniejszenia retencji zlewni. Część stawów młyńskich uległa wypełnieniu osadami i zanikła. Dziś większość z nich już nie istnieje.

Podsumowując wyniki rozważań nad problemem wpływu działalności człowieka związanego z budową i funkcjonowaniem młynów wodnych na obszarze zlewni Obry Skwierzyńskiej, stwierdzić należy, że stanowiły one główny element zagospodarowania zasobów energetycznych i wodnych wód płynących. Poprzez działania mające na celu podpiętrzenie wody w cieku czy odwodnienie terenów podmokłych $\mathrm{w}$ ich sąsiedztwie wpływały na zmiany w ekosystemach dolin rzecznych. Na dużą liczbę młynów wodnych na tym obszarze składało 


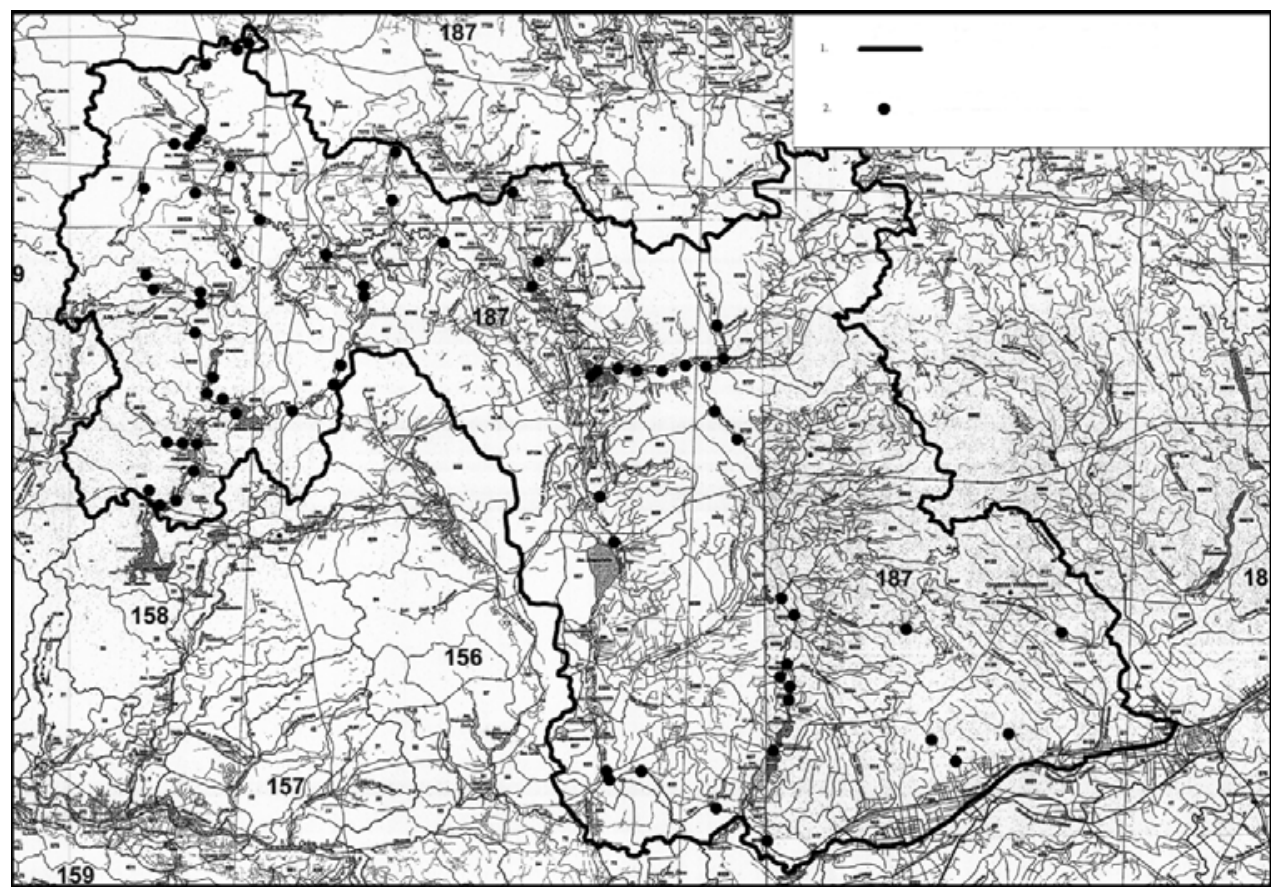

Ryc. 2. Lokalizacja młynów wodnych w końcu XVIII w. (za: J. Gołaski 1988)

1 - granica zlewni Obry Skwierzyńskiej, 2 - wybudowanych w roku 1790

Fig 2. Location of water mills in the end of the XVIIIth century (after: J. Gołaski 1988)

1 - bondary of Skwierzyńska Obra catchment, 2 - water mills build 1790

się kilka przyczyn. Do najważniejszych zaliczyć można małą zdolność przerobową tych zakładów, ograniczoną w dodatku do zaledwie 100-150 dni w roku, dużą ich dochodowość, dążność właścicieli ziemskich do zakładania własnych młynów, wzrost wydajności plonów w XIV w. oraz stosunkowo dużą zasobność wodną cieków tego obszaru. Składa się na to duża liczba jezior na tym obszarze oraz przewaga gruntów sypkich w strefie powierzchniowej, co sprzyjało dużej retencji odpływowej cieków. Ponadto, takie uwarunkowania zmniejszały amplitudy wahań stanów wody w ciekach i tym samym wydłużały czas pracy młynów wodnych. Nie pracowały one bowiem w czasie trwania stanów wysokich, ponieważ groziło to zniszczeniem jego urządzeń, a w czasie trwania stanów niskich z powodu braku wody.

Budowa młynów i związanych z nimi zbiorników wodnych przyczyniała się do regulacji obiegu wody na obszarach zlewni rzecznych. W okresie wezbrań przechwytywały one część nadwyżek wodnych, którymi dysponowano, kiedy wody brakowało.

W dalszych pracach nad tym problemem zamierza się dokonać analizy stopnia zagospodarowania wód powierzchniowych na tym obszarze i oszacować 
dawną retencję zbiornikową, wiążącą się z młynami wodnymi budowanymi na Obrze i jej dopływach. Przyjmuje się, że wynosiła ona około 5\% zasobów dyspozycyjnych (Brykała 2005).

\section{LITERATURA}

Brykała D., 2005: Rekonstrukcja retencji zbiornikowej zlewni Skrwy Lewej w ciagu ostatnich 200 lat. Przegl. Geogr., t. 77, z. 1.

Dembińska M., 1973: Przetwórstwo zboża w Polsce średniowiecznej (X-XIV w.), PAN, IHKM, Ossolineum, Wrocław.

Gołaski J., 1988: Atlas rozmieszczenia młynów wodnych w dorzeczach Warty, Brdy i części Baryczy w okresie 1790-1960, cz. II, Dolna Warta i Obra, Akad. Rol., Poznań.

Hładyłowicz K.J., 1932: Zmiany krajobrazu i rozwoju osadnictwa w Wielkopolsce od XIV do XIX wieku, Lwów.

Kaniecki A., 1993: Poznań. Dzieje miasta woda pisane. Cz. I. Przemiany rzeźby i sieci wodnej, Wyd. Aquarius, Poznań.

Kaniecki A., 1999: Młyny wodne w dawnym Poznaniu i ich wpływ na przeobrażenie stosunków wodnych. Act Univ. N. Copernici, Geogr. 29, UMK, Torun.

Kaniecki A., 2004: Poznań. Dzieje miasta woda pisane. Cz. I-III. Wyd. PTPN, Poznań.

Kodeks Dyplomatyczny Wielkopolski (KDW). T. I-V, J. Zakrzewski, F. Piechociński (red.) (18771908), T. VI-XI A. Gąsiorowski, W. Jurek (red.) (1982-2000), Poznań.

Kondracki J., 1998: Geografia regionalna Polski. Wyd. Nauk. PWN, Warszawa.

Lustracja województw wielkopolskich i kujawskich 1564-1565, 1961, Bydgoszcz.

Łoś M.J., 1978: Likwidacje mlynów wodnych i ich skutki. Gosp. Wodna, R. 38, z. 12.

PODGÓRSKI Z., 2004: Wplyw budowy i funkcjonowania mlynów wodnych na rzeźbe terenu $i$ wody powierzchniowe Pojezierza Chetmińskiego i przyległych części dolin Wisty i Drwęcy. Wyd. UMK, Torun.

Stownik historyczno-geograficzny województwa poznańskiego 1982-2009, oprac. przez: S. Chmielewskiego, K. Górską-Gołaską, J. Lucińskiego, T. Jurka, PAN, Ossolineum i PTPN, Wrocław-Poznań. 